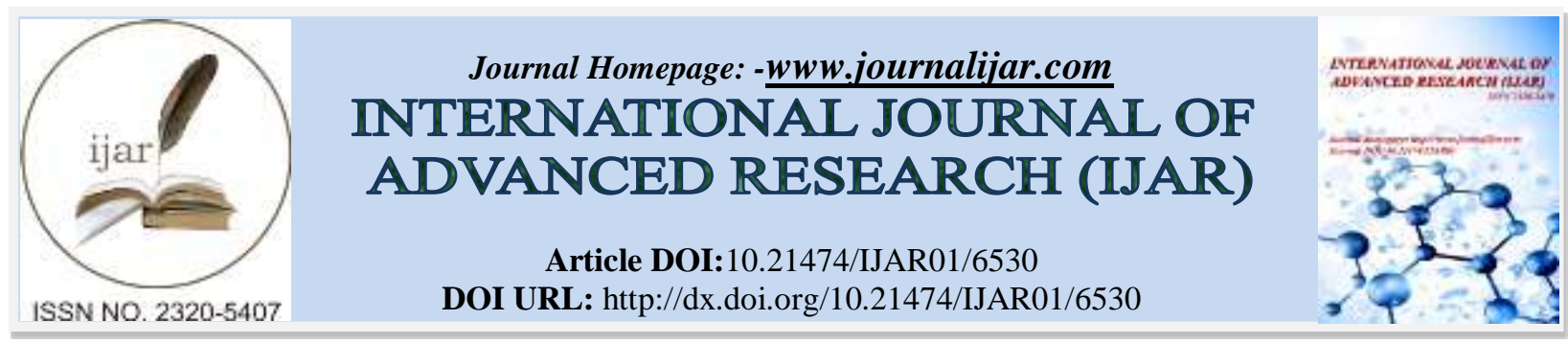

RESEARCH ARTICLE

\title{
PHYTOCHEMICAL, ANTIFUNGAL AND ANTIOXIDANT PROPERTIES OF LEAF EXTRACTS OF THULASIVETTILA AN INDIGENOUS CULTIVAR OF PIPER BETLE L. IN KERALA.
}

Vrinda Raghavan, D. K Sathish and Oommen P Saj.

Department of Botany, University College, Trivandrum, Kerala.

\section{Manuscript Info}

Manuscript History

Received: 14 December 2017

Final Accepted: 16 January 2018

Published: February 2018

Keywords:-

Thulasivettila, antioxidant, DPPH, ascorbic acid.

\section{Abstract}

In the present study, a fine systematic investigation of antioxidant potential of Thulasivettila cultivar of Piper betle L. in Kerala region has been carried out. The results clearly showed chloroform and methanol leaf extracts of this cultivar recorded significant antifungal activity.Phytochemical analysis revealed that phenols, flavonoids, alkaloids, tannins, terpenoids, glycosides are present in Hexane, Chloroform, and Methanol extracts. The antioxidant property of Hexane, Chloroform, and Methanol extracts of Thulasivettila were evaluated by Diphenyl picrynl hydrazyl (DPPH) assay. The extracts of the plant at concentrations of $12.5,25,50,100$, and $200 \mu \mathrm{g} / \mathrm{mL}$ were studied. The Chloroform extract clearly indicate the antioxidant activity of the plant compared with other extracts. The $\mathrm{IC}_{50}$ values were calculated and compared with standard ascorbic acid. The results indicated that the chloroform extract exhibited good scavenging capacity.

Copy Right, IJAR, 2018,. All rights reserved.

\section{Introduction:-}

The Betel (Piper betle L.) is the leaf of a vine belonging to the Piperaceae family. It is a dioeceous creeper mainly cultivated in hotter and damper parts of India, Srilanka, Myanmar, Thailand, and Vietnam. More than100 local cultivars of betel vine are being cultivted in India and are often named after the locality or village where they are grown. The vine is raised by vegetative propagation from the cuttings. Leaves possess activity like carminative, antibiotic, aphrodisiac, expectorant.(Agarwal et.al.2012) The main Ayurvedic preparations of Piper betle plant are Lokantha Rasa, Puspadhava Rasa, Brhat sarwajwarahara, lanha, laghubsutaseknara Rasa. In Ayurveda, betel leaf juice is commonly consumed as an adjuvant and combined with different other medicines. In Susrta Samhita, tambool leaves have been described as aromatic, sharp, hot, acrid and valuable for voice, laxative, appetizer (Kumar, 1999). In Kerala the most prevalent cultivars are Thulasivettila, Venmony, Arikodi, Kalkodi, Karilanchi, Thirur, Amaravila, Cheelanthikarpuram, Pramuttan. Many of these are land races specific to different regions of Kerala rather than district varieties. $P$. betle is cultivated in all districts of Kerala except Idukki, with total area of 349 ha, out of this 183 ha is in Malappuram (FIB, 2014). 'Thulasivettila' is not usually cultivated for commercial purposes as its chewing quality is poor because of its very stringent taste. However, these Thulasivettila has been traditionally used for medicinal purposes and religious and is grown as a household plant. 


\section{Materials and Methods:-}

\section{Plant materials:-}

The plant leaves were collected from Thiruvananthapuram district, Kerala. Healthy and well grown young greenish leaves were collected in sterile polythene bags and transported to the laboratory. The leaves were washed alternatively with tap water, distilled water and shade dried at room temperature.

\section{Preparation of plant extracts:-}

Dried leaves were homogenized into a fine powder by using mixer-grinder. Three different solvents viz., Hexane, Chloroform, and Methanol were used as solvents to extract the bioactive compounds from the sample. About 50 gram of powdered samples were filled in the thimble and extracted exhaustively in a Soxhlet apparatus with $250 \mathrm{ml}$ of respective solvent separately and extracted for about 8hours. The extraction was continued until the extractive become colourless. Finally all the successive were evaporated in rotary vaccum evaporator at $40^{\circ} \mathrm{C}$. The crude extract thus obtained were transferred into glass vials and stored at $4^{0} \mathrm{C}$ until it is required.

\section{Phytochemical analysis:-}

The leaf extracts of 'Thulasivettila' was screened for the presence of various bioactive compounds such as alkaloids, phenols, flavanoids, tannin and glycosides by using standard methods (Harborne,1998).

\section{Alkaloids (Dragendroff's method):-}

The extract was warmed with $10 \mathrm{ml}$ of $2 \%$ sulphuric acid for 2 minutes. A known quantity of sample was treated with a few drops of Dragendroff's reagent .(Glacial acetic acid in a solution of bismuth nitrate and potassium iodide) orange -brown precipitate indicates the presence of alkaloids.

\section{Phenols (Lead acetate test):-}

Alcoholic extract was diluted to $5 \mathrm{ml}$ with distilled water and to this few drops of $1 \%$ aqueous solution of lead acetate was added. A yellow precipate was formed, which indicates the presence of Phenols.

\section{Flavanoids (Shinoda test):-}

The extract was dissolved in methanol and a few pinch of magnesium turnings followed by the addition of concentrated hydrochloric acid drop. Presence of pink colour indicates the presence of flavonoids.

\section{Tannins (Ferric Chloride test)}

To 1-2 $\mathrm{ml}$ of aqueous extract, few drops of $5 \%$ aqueous $\mathrm{Fecl}_{3}$ solution were added. A bluish -black colour,which disappears in addition of a few $\mathrm{ml}_{\text {of }} \mathrm{H}_{2} \mathrm{SO}_{4}$, there is formation of the yellowish brown precipitate confirmed the presence of tannins.

\section{Terpenoids (Libermann-Burchard method):-}

A little of the extract was dissolved in dry chloroform and added three drops of acetic anhydride followed by the addition of two to three drops of concentrated sulphuric acid. The appearance of green colour indicates the presence of terpenoids.

\section{Glycosides (Keller-Killani test):-}

The extracts was dissolved in distilled water and added with $2 \mathrm{ml}$ of glacial acetic acid containing one drop of ferric chloride solution followed by $1 \mathrm{ml}$ of concentrated sulphuric acid along the side of the test tube. The brown ring at the interface represents glycosides.

\section{Antifungal studies:-}

The antifungal activity was determined by Agar well diffusion method. Potato Dextrose agar plates were prepared and overnight grown species of fungus, Aspergillus niger and Candida albicans was swabbed. Wells of approximately $10 \mathrm{~mm}$ was bored using a well cutter and samples of different concentration was added; the zone of inhibition was measured after overnight incubation and compared with that of standard is Clotrimazole(Murray et.al.1995) 


\section{Antioxidant assay:- \\ DPPH assay:-}

DPPH free radical scavenging assay was measured using the method of (Blois,1958/0..Different volumes (12.5$200 \mu \mathrm{g} / \mathrm{ml})$ of plant extracts were made up to $40 \mu \mathrm{l}$ with DMSO and $2.96 \mathrm{ml}$ DPPH $(0.1 \mathrm{mM})$ solution was added. The reaction mixture incubated in dark condition at room temperature for 20 minutes. After 20 minutes, the absorbance of the mixture was read at $517 \mathrm{~nm}$. $3 \mathrm{ml}$ of DPPH was taken as control. Ascorbic acid (10mg/ml DMSO) was used as a standard.

\section{Results and Discussion:-}

Phytochemical composition is a significant factor in determining the antioxidant potential of a plant. Production of free radicals and other reactive species in cells and body tissues has been linked to ageing and several diseases in human being (Rashid H A 2010). Phytochemical studies were conducted to estimate the phytochemical composition of the plant material and antioxidant, antifungal potential also studied.

The results of phytochemical analysis on the three different leaf extracts of the plant revealed the presence of constituents such as alkaloids, phenols, flavonoids, tannins, terpinodes and glycosides(Table.1).The results obtained confirm the earlier reports of some of the phytochemical constituents found in the leaf extract of Piper betle L. (Sita kumara et.al 2014).

Table 1:- Phytochemical screening of different extracts of "Thulasivettila" cultivar of Piper betle.L

\begin{tabular}{|l|l|l|l|}
\hline Phytochemical Constituents & Hexane Extract & $\begin{array}{l}\text { Cloroform } \\
\text { Extract }\end{array}$ & $\begin{array}{l}\text { Methanol } \\
\text { Extract }\end{array}$ \\
\hline Alkaloids & + & + & + \\
\hline Phenols & + & + & + \\
\hline Flavanoids & + & + & + \\
\hline Tannins & + & + & + \\
\hline Terpenoids & + & + & + \\
\hline
\end{tabular}

$+=$ Presence of phytoconstituents, $-=$ Absence of phytoconstituent.

Many plants produce antimicrobial compounds mainly as a defense mechanism against stresses, pathogen attack,etc Taiz and Zeiger,(1991).The activity of the hexane,Chloroform,Methanol leaf extracts of Piper betle against Aspergillus niger and Candida albicans is depicted in Table 2 . The chloroform leaf extract showed a significant activity against Aspergillus niger the plant system itself.

Fig 1:- shows the antifungal activity of the hexanae, chloroform and methanolic extract of P.betle cv thulasi against Aspergillus niger and Candida albicans. The activity of the extract against the microorganisms is visible as clear zone of inhibition that can be measured in millimeter. The chloroform extract showed maximum zone of inhibition at $100 \mu \mathrm{g}$ in $23 \mathrm{~mm}$ against Aspergillus niger and $16 \mathrm{~mm}$ in $100 \mu \mathrm{g}$ against Candida albicans while the methanolic leaf extract showed activity against Aspergillus niger $21 \mathrm{~mm}$ at $100 \mu \mathrm{g}$ and $15 \mathrm{~mm}$ at $100 \mu \mathrm{g}$ against Candida albicans. In Hexane extract showed maximum zone of inhibition at $100 \mu \mathrm{g}$ in $19 \mathrm{~mm}$ against Aspergillus niger and $14 \mathrm{~mm}$ in $100 \mu \mathrm{g}$ against Candida albicans.

Table 2:- Antifungal activity of different extracts of Betel Vine (Piper betle L.) cultivar 'Thulasivettila'

\begin{tabular}{|c|c|c|c|c|c|c|c|c|c|c|}
\hline \multirow{3}{*}{ Fungal strains } & \multirow{3}{*}{$\begin{array}{l}\text { Standard: } \\
\text { Clotrimazole }\end{array}$} & \multicolumn{9}{|c|}{ Zone of inhibition(mm) } \\
\hline & & \multicolumn{3}{|c|}{ Hexane } & \multicolumn{3}{|c|}{ Chloroform } & \multicolumn{3}{|c|}{ Methanol } \\
\hline & & $25 \mu \mathrm{g}$ & $50 \mu \mathrm{g}$ & $\begin{array}{l}100 \\
\mu g\end{array}$ & $25 \mu \mathrm{g}$ & $50 \mu \mathrm{g}$ & $100 \mu \mathrm{g}$ & $25 \mu \mathrm{g}$ & $50 \mu \mathrm{g}$ & $100 \mu \mathrm{g}$ \\
\hline $\begin{array}{l}\text { Aspergillus } \\
\text { niger }\end{array}$ & $25 \mathrm{~mm}$ & 12 & 16 & 19 & 16 & 19 & 23 & 15 & 17 & 21 \\
\hline $\begin{array}{l}\text { Candida } \\
\text { albicans }\end{array}$ & $20 \mathrm{~mm}$ & - & 12 & 14 & 10 & 12 & 16 & 11 & 13 & 15 \\
\hline
\end{tabular}



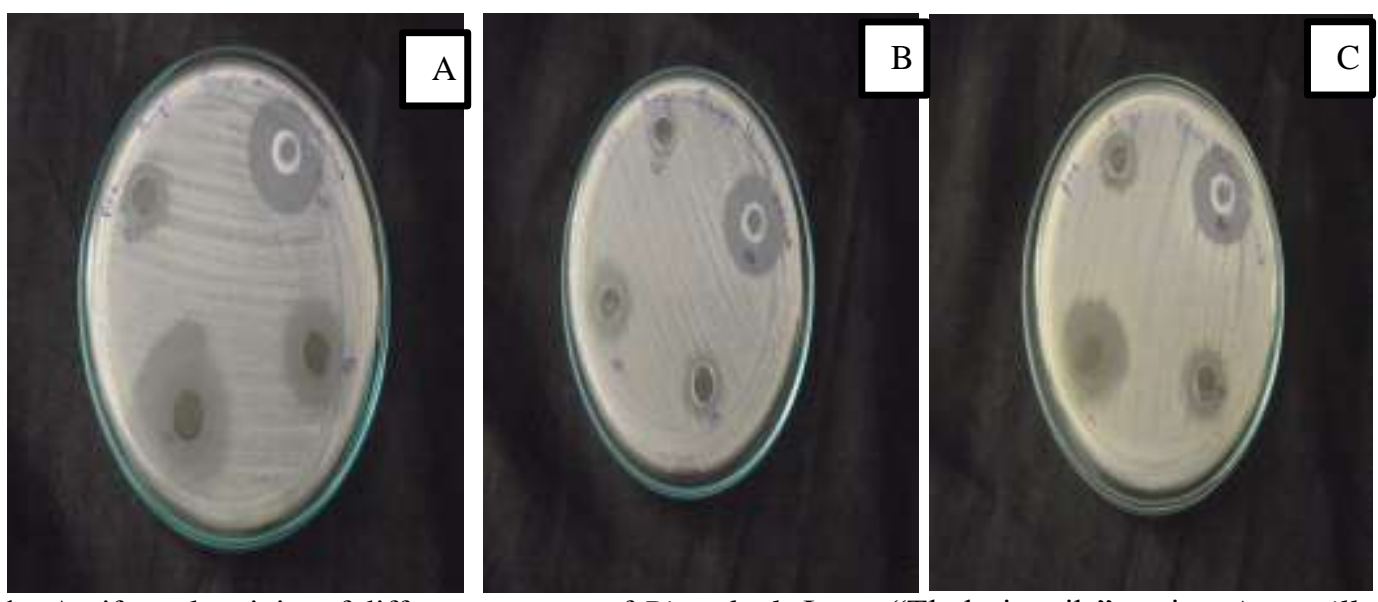

Fig. 1:- Antifungal activity of different extracts of Piper betle L.cv "Thulasivettila" against Aspergillus niger. a) Hexane extract b) Chloroform extract c) Methanol extract.
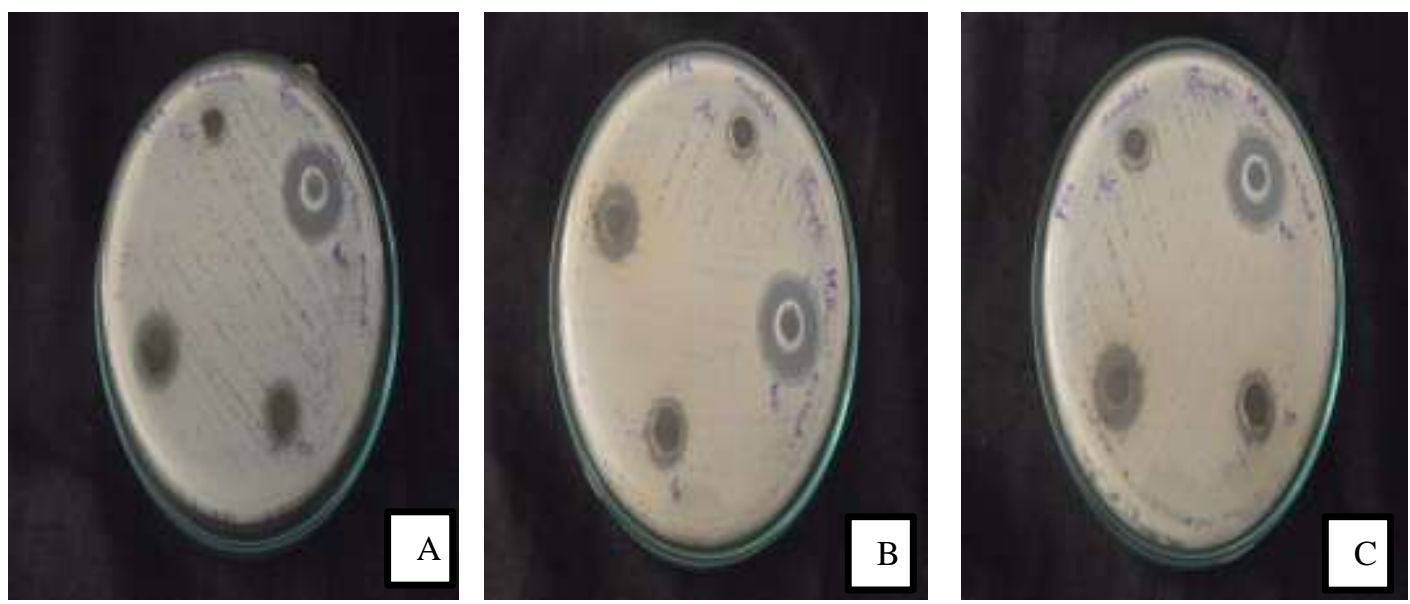

Fig. 2:- Antifungal activity of different extracts of Piper betle L.cv "Thulasivettila" against Candida albicans. a) Hexane extract b) Chloroform extract c) Methanol extract.

In vitro antioxidant studies by DPPH:-

Three different leaf extracts Hexane, chloroform, methanol of Thulasivettila cultivar of Piper betle ranging from $12.5-200 \mu \mathrm{g} / \mathrm{ml}$ was taken respectively was tested for their free radical scavenging potential of the plant extract. The study shows that chloroform leaf extract shows the maximum significant activities compare to standard ascorbic acid is higher than the other two hexane and methanol leaf extracts (Table3).

Table 3:- In -vitro antioxidant studies of Thulasivettila cultivar of Piper betle by DPPH assay.

\begin{tabular}{|l|l|l|l|l|}
\hline \multirow{2}{*}{\begin{tabular}{c} 
Concentration of extracts $(\boldsymbol{\mu g} / \mathbf{m l})$ \\
\cline { 2 - 5 }
\end{tabular}} & Hexane extract & $\begin{array}{l}\text { Chloroform } \\
\text { extract }\end{array}$ & $\begin{array}{l}\text { Methanol } \\
\text { extract }\end{array}$ & $\begin{array}{l}\text { Standard } \\
\text { (Ascorbic acid) }\end{array}$ \\
\hline 12.5 & 45.35 & 49.33 & 44.88 & 46.80 \\
\hline 25 & 49.99 & 52.48 & 51.95 & 53.11 \\
\hline 50 & 50.13 & 68.57 & 64.69 & 72.17 \\
\hline 100 & 57.52 & 87.11 & 88.22 & 78.94 \\
\hline 200 & 69.14 & 92.25 & 90.94 & 83.67 \\
\hline
\end{tabular}

$\mu \mathrm{g} / \mathrm{ml}-$ Microgram per Millilitre 


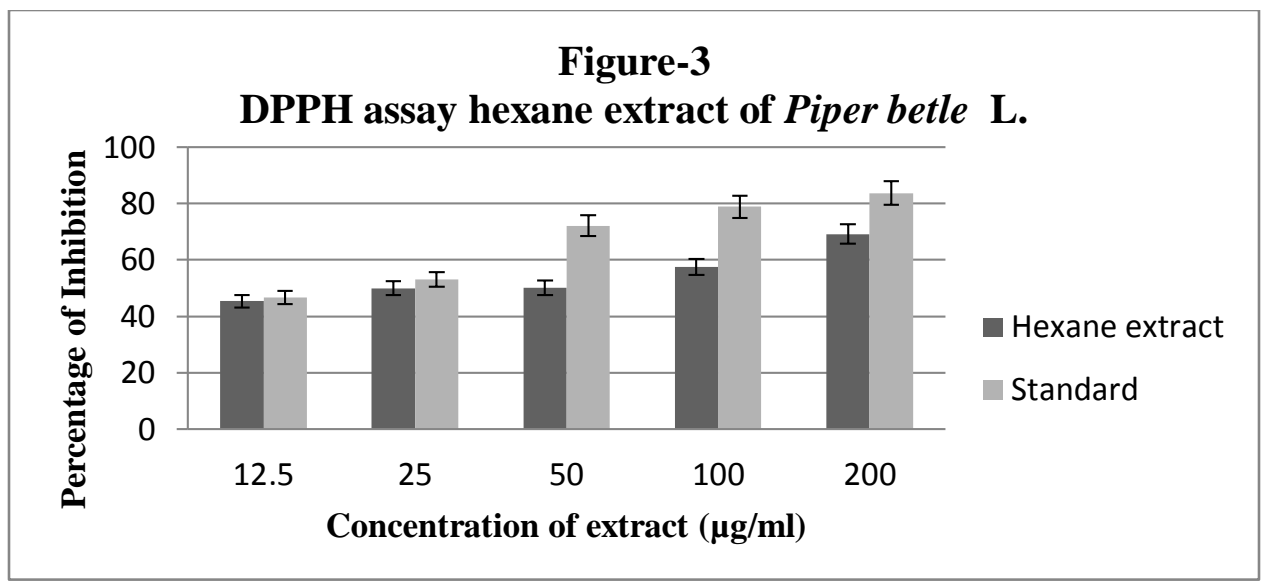

The DPPH radical scavenging activity of the hexane leaf extract at $200 \mu \mathrm{g} / \mathrm{ml}$ was $69.14 \%$ and the standard ascorbic acid was $83.67 \%$ (Table1 and Figure3).The results shows that the hexane extract exhibited moderate DPPH scavenging ability $\left(\mathrm{IC}_{50}\right.$ value of $\left.50 \mu \mathrm{g} / \mathrm{ml}\right)$ than the ascorbic acid( $\mathrm{IC}_{50}$ value of $20 \mu \mathrm{g} / \mathrm{ml}$ )in (Figure 6 ).

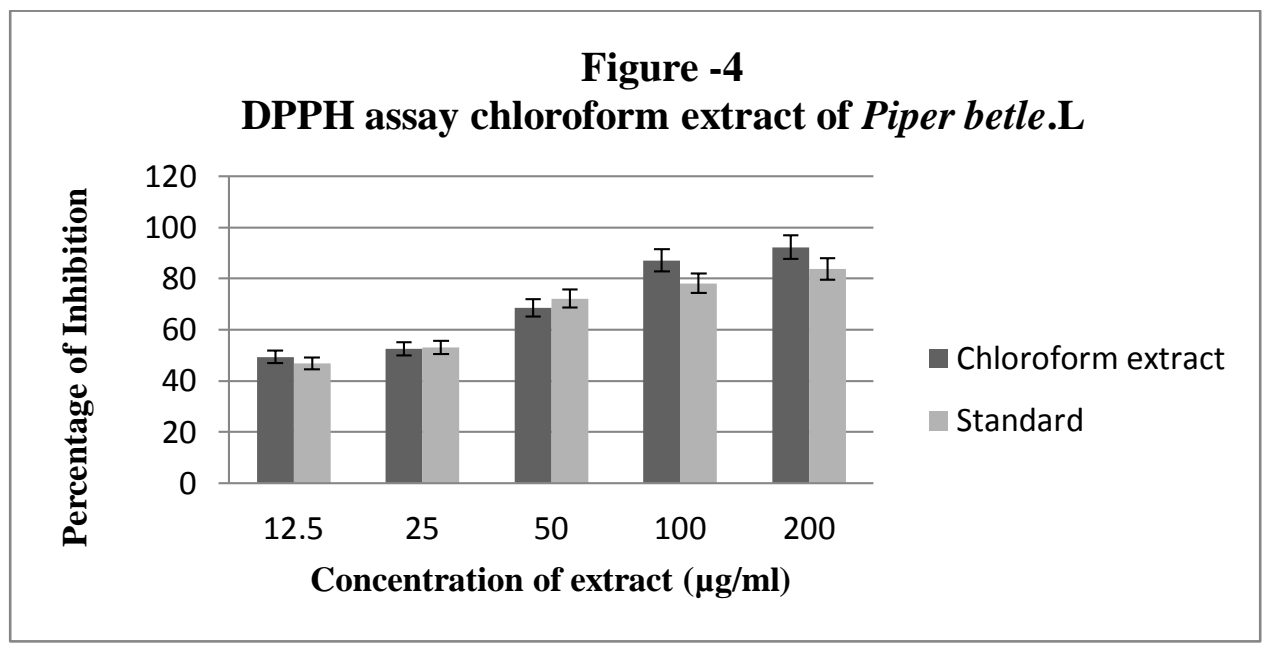

In Chloroform leaf extract at $200 \mu \mathrm{g} / \mathrm{ml}$ was $92.25 \%$ and that of the standard ascorbic acid was $83.67 \%$ (Table1 and Figure4).The results shows that the chloroform extract exhibited maximum DPPH scavenging ability (IC 50 value of $17.5 \mu \mathrm{g} / \mathrm{ml}$ ) than the ascorbic acid ( $\mathrm{IC}_{50}$ value of $20 \mu \mathrm{g} / \mathrm{ml}$ ) in (Figure 6).

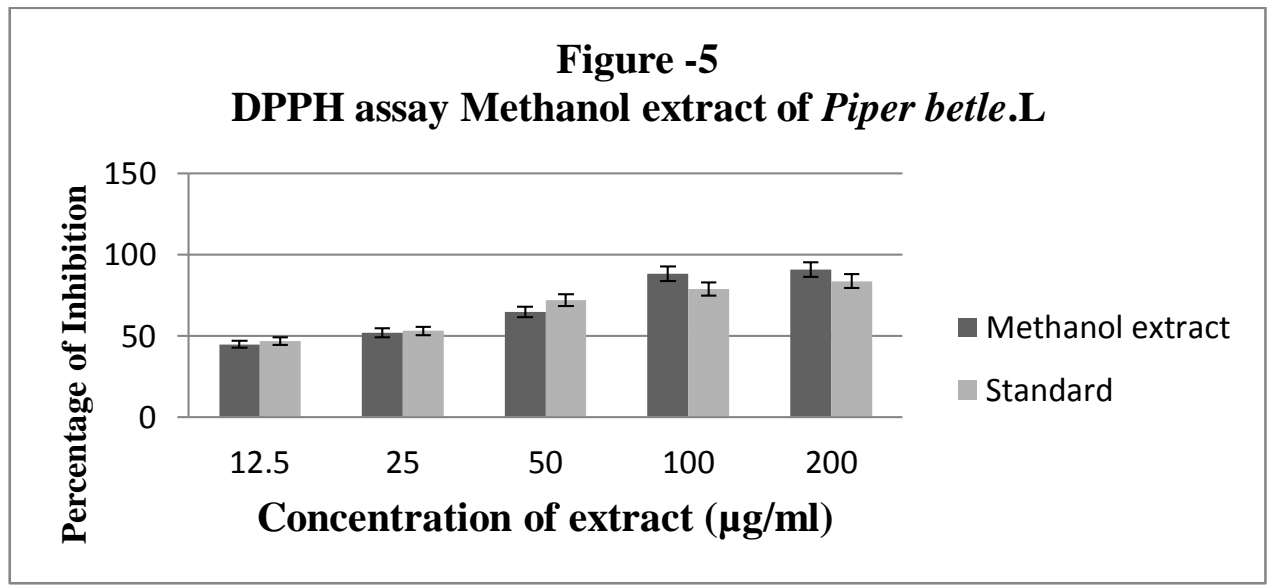

In methanol leaf extract, at $200 \mu \mathrm{g} / \mathrm{ml}$ inhibition was $90.94 \%$ and that of the standard ascorbic acid was $83.67 \%$ (Table1 and Figure3).The results shows that the methanol extract exhibited significant scavenging ability ( $\mathrm{IC}_{50}$ value 
of $22.5 \mu \mathrm{g} / \mathrm{ml}$ ) than the ascorbic acid( $\left(\mathrm{IC}_{50}\right.$ value of $\left.20 \mu \mathrm{g} / \mathrm{ml}\right)$ in (Figure 6). This result confirmed that the strong free radical scavenging ability was observed in chloroform extract of the Piper betle L. cv Thulasivettila.

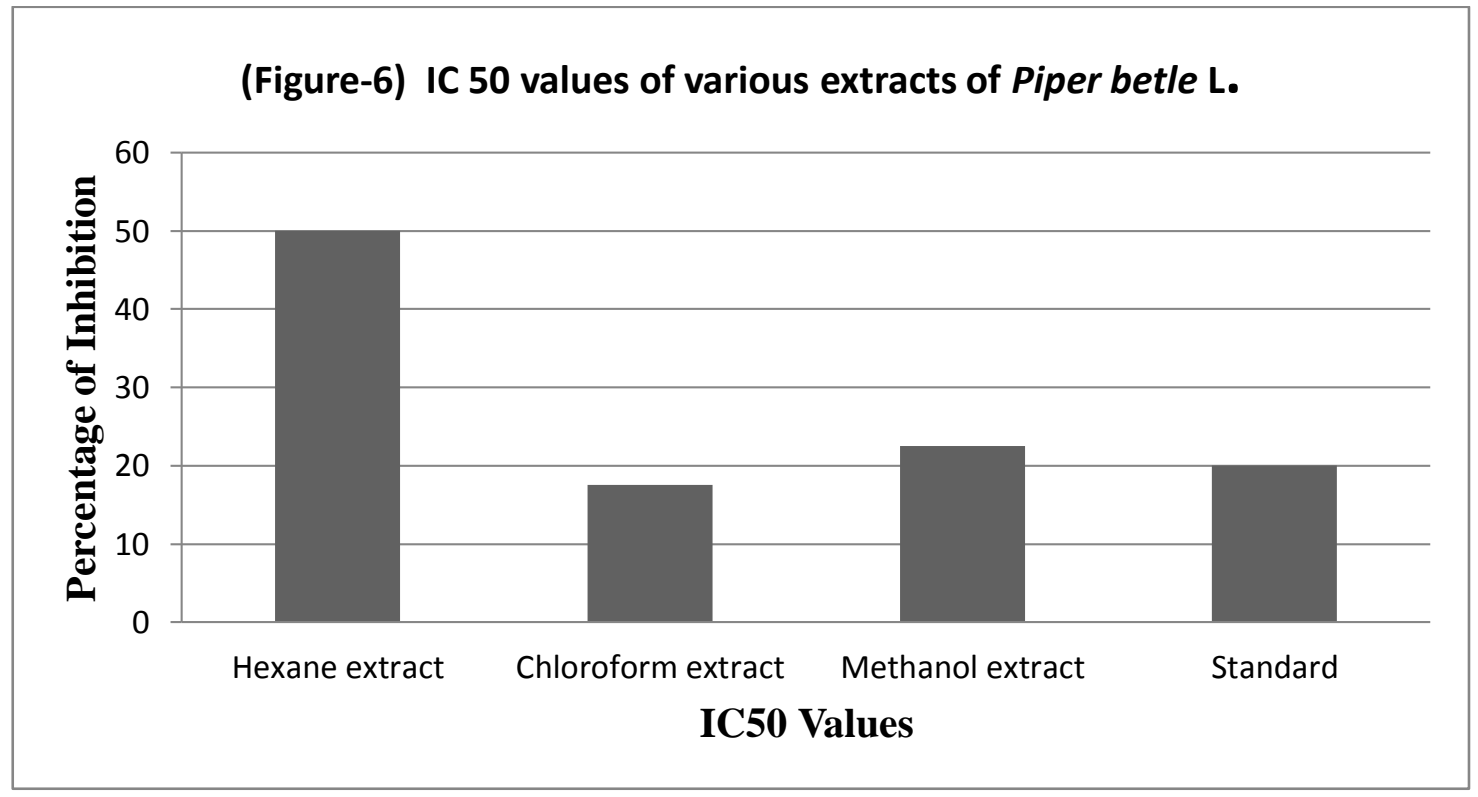

\section{Conclusions:-}

The present study showed that the free radical scavenging potential of the 'thulasivettila' a domestic cultivar of P.betle. The Chloroform leaf extract of "Thulasivettila" P.betle showed more antioxidant activity and may be due to the presence of phytochemical constituents in this extract compared with other extracts. Due to its high potential it may be used as an effective antioxidant agent for developing new medicines in the coming years. More studies are needed to determine the major roles of these phytochemical constitutents present in 'Thulasivettila' a cultivar of Piper betle L.

\section{Acknowledgements:-}

The authors are thankful to University Grant Commission for the financial support.

\section{References:-}

1. Amonkar, A.J., Padma, P.R. and Bhide, S.V. (1989): Protective effect of hydroxychavicol,a phenolic component of betel leaf against the tobacco-specific carcinogens.Mutal.Res.Journal,210 (2), 249-253.

2. Blois., M .S (1958): Antioxidant determination by use of stable free radical. Nature 181:1199-1200.

3. Farm Guide (2014): (FIB) Farm Information Bureau.Government of Kerala (2014):pp. 256.

4. Harborne,J.B. (1998): Methods of extraction and isolation In :Phytochemical methods 60-66, Chapman and Hall ,London.

5. Kumar,N. (1999): Betel Vine (Piper betle L.) Cultivation: A unique case of plant establishment under anthropogenically regulated microclimatic conditions. Indian Journal of Science, 34(1):19-32.

6. Murray, P.R., Baron, E.J., Pffaller, M.A., Tenover, F.C., and H.R. Yolkern. (1995). Manual of Clinical Microbiology 6 th edition ASM Press, Washington, DC 15-18

7. Rashid,H.A., Qureshi, M. Z., Raza ,S .A .,William ,J., and Arshad M. (2010):Quantitative determination of antioxidant potential of Artemisia persica. Ann Univ Bucuresti Chim (119):452-458.

8. Sita kumara, O. and Nirmala Babu Rao. (2014): Phytochemical analysis of Piper betle leaf extract. World journal of pharmacy and pharmaceutical science.(4):700-703.

9. Taiz,L. and Zeiger, E. (1991):Plant Physiology .The Benjamin Cummings publishing Company.Inc.California.pp.318-343. 